OPEN ACCESS

Edited by:

Huaqiang Zeng,

A*STAR, Singapore

Reviewed by:

Mihail Barboiu,

UMR5635 Institut Européen des Membranes (IEM), France

Junqiu Liu,

Hangzhou Normal University, China

*Correspondence:

Chunyan Bao

baochunyan@ecust.edu.cn

Specialty section:

This article was submitted to

Chemical Biology,

a section of the journal

Frontiers in Chemistry

Received: 13 February 2021 Accepted: 06 April 2021

Published: 29 April 2021

Citation:

Wang $C$, Yang $H$, Xiang $Y$, Pang $S$, Bao $C$ and Zhu L (2021) A Synthetic

Phospholipid Derivative Mediates Ion

Transport Across Lipid Bilayers.

Front. Chem. 9:667472.

doi: 10.3389/fchem.2021.667472

\title{
A Synthetic Phospholipid Derivative Mediates Ion Transport Across Lipid Bilayers
}

Chenxi Wang, Huiting Yang, Yanxin Xiang, Shihao Pang, Chunyan Bao* and Linyong Zhu

Shanghai Key Laboratory of Functional Materials Chemistry, School of Chemistry and Molecular Engineering, East China

University of Science and Technology, Shanghai, China

Inspired by the natural phospholipid structures for cell membrane, a synthetic phospholipid LC with an ion recognition group benzo-18-crown-6 (B18C6) moiety was prepared which has been demonstrated to be able to transport ions across the lipid bilayers. Fluorescent vesicle assay shows that LC has an excellent transport activity, and the $\mathrm{EC}_{50}$ value for $\mathrm{K}^{+}$is $11.2 \mu \mathrm{M}$. The voltage clamp measurement exhibits regular square-like current signals with considerably long opening times, which indicates that LC achieves efficient ion transport through a channel mechanism and its single channel conductivity is $17 \mathrm{pS}$. Both of the vesicle assay and patch clamp tests indicate that LC has selectivity for $\mathrm{Rb}^{+}$, whose ionic radius is larger than the cavity of crown ether. It suggests that the sandwich interaction may play a key role in the ion transport across lipid bilayers. All these results help us to speculate that $\mathbf{L C}$ transports ions via a channel mechanism with a tetrameric aggregate as the active structure. In addition, LC had obvious toxicity to HeLa cells, and the $\mathrm{IC}_{50}$ was $100.0 \mu \mathrm{M}$ after coculture for $36 \mathrm{~h}$. We hope that this simple synthetic phospholipid will offer novel perspectives in the development of more efficient and selective ion transporters.

Keywords: synthetic phospholipids, artificial membrane transporter, channel, relay mechanism, ion selectivity

\section{INTRODUCTION}

Cell is the basic unit of structure and function for all organisms. Cell membrane is not only the barrier for cell to survive independently, but also the medium for cell to contact with the surrounding environment and other cells. It can maintain the survival of life through substance exchange, signal transduction and energy conversion. Although some non-polar molecules can be transported inside and outside the cell membrane through free diffusion, the transport of polar solutes and biomacromolecules, such as ions, glucose, amino acids, etc., requires the assistance of specific membrane transporters through carrier or channel mechanisms (Appleman and Lienhard, 1989; Lang et al., 2005; Bröer, 2008; Mosgaard and Heimburg, 2013).

Considering the energy required for the ion to move across the bilayer membrane, the ion transporter should provide enough intermolecular interaction to compensate for the loss of ion hydration energy. Therefore, ion transport through membrane is actually a supramolecular function (Fyles, 2007). Inspired by the functional sophistication of ion transporters in nature, supramolecular chemists have created a variety of synthetic systems to replicate the transport functions by using small molecules and synthetic compounds (Kim and Sessler, 2015; Si et al., 2015; Chen et al., 2018a,b, 2020; Wu et al., 2018; Zhang et al., 2019; Zheng et al., 2020). It is of biological 
importance to build artificial ion transporters with desired properties, which will not only help to elucidate the possible mechanism by biological transporters, but also to provide early diagnosis and potential medical applications for the treatment of diseases caused by structural and functional abnormalities (such as "channelopathies") (Zaydman et al., 2012).

In the design of synthetic transporters, most reported compounds have hydrophobic structures to facilitate the insertion of hydrophobic phospholipid bilayer membrane (Kim and Sessler, 2015; Si et al., 2015; Wu et al., 2018; Zheng et al., 2020). However, there are two obvious shortcomings in such a design, including the requirement of organic solvents to solute the compounds and the competitive self-precipitation in physiological solution before inserting in lipid membrane. The use of additional organic solvents increases the biological toxicity and the competitive self-precipitation reduces the transport activity, which affect the further application of these artificial transporters in pharmaceutical areas. Some watersoluble peptides have been reported to undergo supramolecular self-assembly to transport ions when exposed to membranes (Shank et al., 2006; Elliott et al., 2008). Complex design and synthetic procedures limit the structural diversity of watersoluble peptide transporters to a certain extent. It is known that the main component of cell membrane is the mixture of phospholipids, and the membrane is composed of two layers of phospholipid molecules arranged symmetrically. If the structure of phospholipids is combined with an ion recognition group, it provides an alternative option to develop efficient ion transporters. This kind of ion transporters will have the following two advantages: the zwitterionic structure can solve the above water solubility problem, and the phospholipid-like structure also increases its interaction with the membrane. Up to now, synthetic phospholipids with ion transport ability have very seldom been reported. A typical work was reported by the Smith group, in which a series of phosphatidylcholine derivatives containing different $\mathrm{Cl}^{-}$recognition groups have been confirmed to transport $\mathrm{Cl}^{-}$across the lipid bilayers by a relay mechanism (McNally et al., 2008). They detailed studied the effect of membrane thickness on $\mathrm{Cl}^{-}$influx rates and proposed two possible relay mechanisms by a dimeric or a tetrameric aggregate.

Taking inspiration from above relay mechanism, we herein reported a new synthetic phospholipid LC which can perform cation transport across the lipid membranes. As shown in Scheme 1, transporter LC contains a benzo-18-crown-6 (B18C6) group with relatively high affinity for cations. The amphipathic of LC allows all transport analysis to be performed in buffer solutions without using any organic solvents, and the phospholipid structure enables LC to strongly interact with the membrane, thus achieving efficient ion transport from one side of the membrane to the other. Ion selectivity analysis and voltage clamp single-channel current recording suggested that ion transport of LC is more likely to be mediated by the channel mechanism of a tetrameric aggregate. Excellent transport activity and cytotoxicity to cancer cells will facilitate the application of synthetic phospholipid transporters in biomedical research.

\section{MATERIALS AND METHODS}

\section{Materials}

All starting materials were obtained from commercial suppliers and were used without further purification unless otherwise stated. All air- or moisture-sensitive reactions were performed using oven-dried or flame-dried glassware under an inert atmosphere of dry argon. Egg yolk phosphatidylcholine (EYPC) and 1,2-diphytanoyl-sn-glycero-3-phosphocholine (DPhPC) were obtained from Avanti Polar lipids as powder. 8-hydroxy-
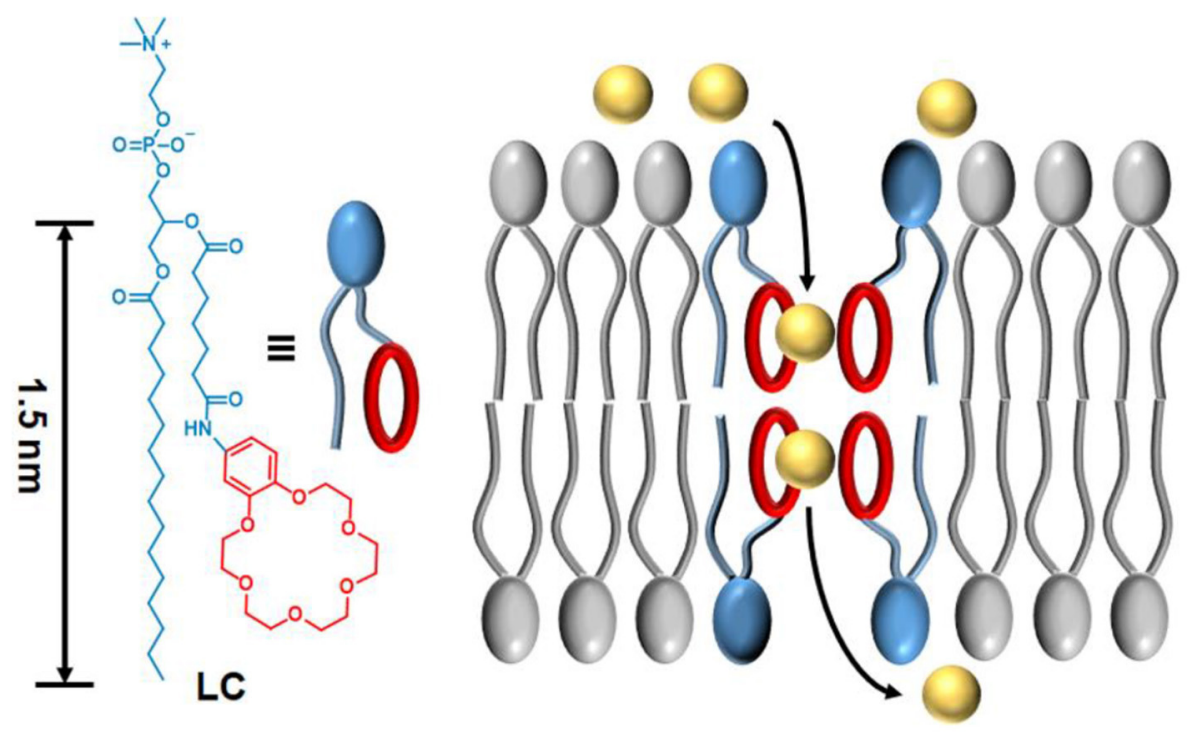

SCHEME 1 | The molecular structure of synthetic phospholipid LC and the proposed transport mechanism across a lipid membrane. 
1,3,6-pyrenetrisulfonate (HPTS) and Triton X-100 were obtained from Sigma Aldrich and used without further purification.

\section{Characterizations}

Proton and carbon nuclear magnetic resonance spectra $\left({ }^{1} \mathrm{H}\right.$, ${ }^{13} \mathrm{C}$ NMR) were recorded on a Bruker Avance $400 \mathrm{MHz} / 600$ $\mathrm{MHz}$ spectrometer. Mass spectra were recorded on a Micromass GCTTM and a Micromass LCTTM. Fluorescence measurements were performed on a Varian Cary Eclipses fluorescence spectrometer equipped with a stirrer and a temperature controller (kept at $25^{\circ} \mathrm{C}$ unless otherwise noted). A MiniExtruder used for the preparation of LUVs was purchased from Avanti Polar lipids. The size of EYPC vesicles was determined using a Delsa ${ }^{\mathrm{TM}}$ Nano Submicron Particle Size and Zeta Potential Particle Analyzer (Beckman Coulter Inc., USA). Preparative reverse phase HPLC was performed using a Waters 2454 Multisolvent Delivery System with a Waters 2489 UV/visible detector operating at $254 \mathrm{~nm}$.

\section{Synthesis of Compounds Compound S1}

To a solution of 4-nitrocatechol ( $1.0 \mathrm{~g}, 6.45 \mathrm{mmol})$ in acetonitrile (300 mL) was added S0 (Chen et al., 2018a) (8.8 g, $16.1 \mathrm{mmol})$ and $\mathrm{K}_{2} \mathrm{CO}_{3}$ (5.5 g, $40 \mathrm{mmol}$ ). The mixture was refluxed at $90^{\circ} \mathrm{C}$ for $12 \mathrm{~h}$. Then, the mixture was cooled to room temperature and filtered. Finally, the solvent was removed under vacuum to obtain the crude product, which was further purified by silica gel flash column chromatography $(\mathrm{DCM} / \mathrm{MeOH}=100: 1)$ to afford yellow powder compound S1 (1.66 g, 72\% yield). ${ }^{1} \mathrm{H}$ NMR $(600 \mathrm{MHz}$, $\left.\mathrm{CDCl}_{3}\right) \delta=7.89(\mathrm{dd}, J=8.9,2.6 \mathrm{~Hz}, 1 \mathrm{H}), 7.74(\mathrm{~d}, J=2.7 \mathrm{~Hz}$, $1 \mathrm{H}), 6.89(\mathrm{~d}, J=8.9 \mathrm{~Hz}, 1 \mathrm{H}), 4.29-4.19(\mathrm{~m}, 4 \mathrm{H}), 4.01-3.91(\mathrm{~m}$, $4 \mathrm{H}), 3.78(\mathrm{dq}, J=5.9,2.2 \mathrm{~Hz}, 4 \mathrm{H}), 3.74-3.70(\mathrm{~m}, 4 \mathrm{H}), 3.69(\mathrm{~s}$, $4 \mathrm{H}) .{ }^{13} \mathrm{C} \mathrm{NMR}\left(151 \mathrm{MHz}, \mathrm{CDCl}_{3}\right) \delta=154.46,148.50,141.43$, 117.97, 111.34, 108.30, 71.04, 70.64, 69.20. MS (ESI): m/z: Calcd. for $\mathrm{C}_{16} \mathrm{H}_{24} \mathrm{NO}_{8}^{+}[\mathrm{M}+\mathrm{H}]^{+}$: 358.2. Found: 358.1.

\section{Compound S2}

To a solution of $\mathbf{S 1}(5.0 \mathrm{~g}, 14 \mathrm{mmol})$ in dichloromethane $(200 \mathrm{~mL})$ was added $10 \% \mathrm{Pd} / \mathrm{C}(0.2 \mathrm{~g})$. The mixture was stirred at room temperature under hydrogen (balloon) atmosphere and monitored by thin layer chromatography. After the reduction reaction was completed, $\mathrm{Pd} / \mathrm{C}$ was filtered and the solvent was removed under vacuum. The crude product was further purified by silica gel flash column chromatography $(\mathrm{DCM} / \mathrm{MeOH}=$ 100:10) to afford colorless oil compound S2 (3.4 g, 74\% yield). ${ }^{1} \mathrm{H} \mathrm{NMR}\left(400 \mathrm{MHz}, \mathrm{CDCl}_{3}\right) \delta=6.72(\mathrm{~d}, J=8.4 \mathrm{~Hz}, 1 \mathrm{H}), 6.30$ $(\mathrm{d}, J=2.6 \mathrm{~Hz}, 1 \mathrm{H}), 6.23(\mathrm{dd}, J=8.4,2.6 \mathrm{~Hz}, 1 \mathrm{H}), 4.12-4.04(\mathrm{~m}$, $4 \mathrm{H}), 3.91(\mathrm{dd}, J=5.7,3.7 \mathrm{~Hz}, 2 \mathrm{H}), 3.87(\mathrm{dd}, J=5.8,3.8 \mathrm{~Hz}, 2 \mathrm{H})$, 3.78-3.69 (m, 8H), $3.68(\mathrm{~s}, 4 \mathrm{H}) .{ }^{13} \mathrm{C} \mathrm{NMR}\left(151 \mathrm{MHz}, \mathrm{CDCl}_{3}\right)$ $\delta=150.00,142.28,116.77,108.19,103.31,70.75,69.93,69.66$, 68.70. MS (ESI): m/z: Calcd. for $\mathrm{C}_{16} \mathrm{H}_{26} \mathrm{NO}_{6}^{+}[\mathrm{M}+\mathrm{H}]^{+}$: 328.2. Found: 328.2.

\section{Compound S3}

Under Argon atmosphere, 1-chloro-N,N-2-trimethylprop-1-en1-ylamine ( $2.7 \mathrm{~g}, 20 \mathrm{mmol}$ ) was added to a solution of monoethyl heptanedioate $(3.0 \mathrm{~g}, 15.9 \mathrm{mmol})$ in dry dichloromethane
$(50 \mathrm{~mL})$. The mixture was stirred at room temperature for $3 \mathrm{~h}$. After removing the solvent under vacuum, the obtained acyl chloride was re-dissolved in dry dichloromethane $(20 \mathrm{~mL})$ for use. Then, to a solution of $\mathbf{S 2}(3.3 \mathrm{~g}, 10 \mathrm{mmol})$ in $20 \mathrm{~mL}$ dichloromethane was added above acyl chloride solution dropwise. The obtained mixture was kept stirring at room temperature for $12 \mathrm{~h}$ and the crude product was obtained under vacuum, which was further purified by silica gel flash column chromatography (DCM/MeOH $=100: 5)$ to afford white powder compound S3 (3.1 g, 62\% yield). $\left.{ }^{1} \mathrm{H} \mathrm{NMR} \mathrm{(400} \mathrm{MHz}, \mathrm{CDCl}_{3}\right) \delta$ $=7.54(\mathrm{~d}, J=9.2 \mathrm{~Hz}, 1 \mathrm{H}), 7.37(\mathrm{~d}, J=2.4 \mathrm{~Hz}, 1 \mathrm{H}), 6.87(\mathrm{dd}$, $J=8.6,2.4 \mathrm{~Hz}, 1 \mathrm{H}), 6.79(\mathrm{dd}, J=8.6,1.7 \mathrm{~Hz}, 1 \mathrm{H}), 4.21-4.05$ $(\mathrm{m}, 6 \mathrm{H}), 3.89(\mathrm{dt}, J=6.7,3.2 \mathrm{~Hz}, 4 \mathrm{H}), 3.81-3.65(\mathrm{~m}, 12 \mathrm{H}), 2.32$ $(\mathrm{dtd}, J=11.9,7.5,4.3 \mathrm{~Hz}, 4 \mathrm{H}), 1.68(\mathrm{ddt}, J=34.4,15.2,7.5 \mathrm{~Hz}$, $4 \mathrm{H}), 1.47-1.33(\mathrm{~m}, 2 \mathrm{H}), 1.25(\mathrm{td}, J=7.1,3.1 \mathrm{~Hz}, 3 \mathrm{H}) .{ }^{13} \mathrm{C} \mathrm{NMR}$ $\left(151 \mathrm{MHz}, \mathrm{CDCl}_{3}\right) \delta=173.80,171.76,145.70,142.23,133.50$, $112.56,110.73,104.42,60.28,50.83,45.89,34.10,28.72,24.66$, 14.27, 8.65. MS (ESI): m/z: Calcd. for $\mathrm{C}_{25} \mathrm{H}_{39} \mathrm{NO}_{9} \mathrm{~K}^{+}[\mathrm{M}+\mathrm{K}]^{+}$: 536.2. Found: 536.3 .

\section{Compound S4}

To a solution of $\mathbf{S 3}(1.0 \mathrm{~g}, 2 \mathrm{mmol})$ in $\mathrm{MeOH} / \mathrm{H}_{2} \mathrm{O}(\mathrm{V}: \mathrm{V}=$ 9:1, $100 \mathrm{~mL})$ was added $\mathrm{KOH}(0.5 \mathrm{~g}, 8.9 \mathrm{mmol})$. The mixture was stirred at room temperature for $12 \mathrm{~h}$. Then, the $\mathrm{pH}$ of the solution was adjusted to 7.0 by addition of $\mathrm{HCl}$ aqueous solution ( $1 \mathrm{M})$. The solvent was removed under vacuum and the residue was dissolved with $20 \mathrm{~mL} \mathrm{MeOH}$. After filtratio, the residue was purified by reverse phase preparative HPLC $\left(\mathrm{MeOH} / \mathrm{H}_{2} \mathrm{O}=\right.$ from 30:70 to 100:0 in $25 \mathrm{~min}$ ) to afford white powder compound S4 (0.4 g, 42.6\% yield). ${ }^{1} \mathrm{H}$ NMR (400 $\left.\mathrm{MHz} \mathrm{CDCl}_{3}\right) \delta=8.97$ (s, $1 \mathrm{H}), 7.37(\mathrm{~d}, J=2.3 \mathrm{~Hz}, 1 \mathrm{H}), 7.09(\mathrm{dd}, J=8.7,2.2 \mathrm{~Hz}, 1 \mathrm{H})$, $6.70(\mathrm{~d}, J=8.7 \mathrm{~Hz}, 1 \mathrm{H}), 4.06(\mathrm{t}, J=4.7 \mathrm{~Hz}, 4 \mathrm{H}), 3.83(\mathrm{dd}$, $J=16.3,4.3 \mathrm{~Hz}, 4 \mathrm{H}), 3.74-3.58(\mathrm{~m}, 12 \mathrm{H}), 2.27(\mathrm{dt}, J=41.0$, $7.4 \mathrm{~Hz}, 4 \mathrm{H}), 1.56(\mathrm{dp}, J=46.2,7.2 \mathrm{~Hz}, 4 \mathrm{H}), 1.27(\mathrm{~d}, J=9.0 \mathrm{~Hz}$, $2 \mathrm{H}) .{ }^{13} \mathrm{C} \mathrm{NMR}\left(151 \mathrm{MHz}, \mathrm{CDCl}_{3}\right) \delta=176.56,170.68,147.90$, $144.25,131.43,113.59,111.53,106.09,69.66,68.52,67.72,52.42$, 36.04, 32.70, 28.68, 27.43, 24.17, 23.30. MS (ESI): m/z: Calcd. for $\mathrm{C}_{23} \mathrm{H}_{35} \mathrm{NO}_{9} \mathrm{Na}^{+}[\mathrm{M}+\mathrm{Na}]^{+}:$492.2. Found 492.1.

\section{Compound LC}

To a solution of 1-palmitoyl-2-hydroxy-sn-glycero-3phosphocholine (Lyso PC, $20.0 \mathrm{mg}, 0.04 \mathrm{mmol}$ ) in DMF $(1 \mathrm{~mL})$ was added $\mathbf{S 4}(94.0 \mathrm{mg}, 0.2 \mathrm{mmol})$, EDC (38.0 g, 0.2 mmol) and DMAP (5.0 mg, $0.04 \mathrm{mmol}$ ). The mixture was stirred at room temperature for 2 days. After the reaction was completed, the mixture was diluted with $20 \mathrm{~mL} \mathrm{MeOH} / \mathrm{H}_{2} \mathrm{O}$ $(\mathrm{V}: \mathrm{V}=1: 1)$ and purified by reverse phase preparative HPLC $\left(\mathrm{MeOH} / \mathrm{H}_{2} \mathrm{O}=\right.$ from $50: 50$ to $100: 0$ in $\left.25 \mathrm{~min}\right)$ to afford colorless oil compound LC (13 mg, 34.3\% yield). ${ }^{1} \mathrm{H}$ NMR $(400 \mathrm{MHz}$, $\left.\mathrm{CDCl}_{3}\right) \delta=10.06(\mathrm{~s}, 1 \mathrm{H}), 7.51(\mathrm{~d}, J=2.3 \mathrm{~Hz}, 1 \mathrm{H}), 7.17(\mathrm{dd}, J=$ 8.6, 2.2 Hz, $1 \mathrm{H}), 6.77(\mathrm{~d}, J=8.7 \mathrm{~Hz}, 1 \mathrm{H}), 5.24(\mathrm{tt}, J=7.2,3.8 \mathrm{~Hz}$, $1 \mathrm{H}), 4.22-4.00(\mathrm{~m}, 8 \mathrm{H}), 3.85(\mathrm{q}, J=4.1 \mathrm{~Hz}, 4 \mathrm{H}), 3.69(\mathrm{t}, J=$ $4.7 \mathrm{~Hz}, 4 \mathrm{H}), 3.64(\mathrm{~d}, J=9.9 \mathrm{~Hz}, 8 \mathrm{H}), 3.53(\mathrm{~d}, J=4.9 \mathrm{~Hz}, 2 \mathrm{H}), 3.14$ (s, 9H), 2.51-2.17 (m, 6H), $1.62(\mathrm{ddq}, J=37.2,14.3,7.1 \mathrm{~Hz}, 6 \mathrm{H})$, $1.40(\mathrm{q}, J=7.1 \mathrm{~Hz}, 2 \mathrm{H}), 1.25(\mathrm{~s}, 26 \mathrm{H}), 0.88(\mathrm{t}, J=6.6 \mathrm{~Hz}, 3 \mathrm{H})$. ${ }^{13} \mathrm{C} \mathrm{NMR}\left(151 \mathrm{MHz}, \mathrm{CDCl}_{3}\right) \delta=173.60,173.36,172.54,148.23$, $144.26,133.82,113.74,112.66,106.83,70.82,70.37,70.22,69.57$, 
$69.49,68.91,68.46,66.44,64.11,62.73,59.06,54.44,36.93,34.12$, 31.93, 29.71, 29.37, 29.16, 28.06, 24.58, 22.70, 14.14. HRMS (ESI): $\mathrm{m} / \mathrm{z}$ : Calcd. for $\mathrm{C}_{47} \mathrm{H}_{84} \mathrm{~N}_{2} \mathrm{O}_{15} \mathrm{PNa}^{2+}[\mathrm{M}+\mathrm{Na}+\mathrm{H}]^{2+}$ : 485.2748 . Found 485.2738.

\section{Dynamic Light Scattering Analyses}

(a) Preparation of large unilamella vesicles (LUVs): To an EYPC solution $\left(10.0 \mathrm{mg}, 400 \mu \mathrm{L}, 25.0 \mathrm{mg} \mathrm{mL}^{-1}\right.$ in $\left.\mathrm{CHCl}_{3}\right)$ was added cholesterol ( $1.0 \mathrm{mg}, 100 \mu \mathrm{L}, 10 \mathrm{mg} \mathrm{mL}^{-1}$ in $\mathrm{CHCl}_{3}$ ). The solvent was evaporated by a slow stream of nitrogen, followed by drying under vacuum for $12 \mathrm{~h}$. Then, the lipid membrane was hydrated with $500 \mu \mathrm{L}$ HEPES buffer (10 mM HEPES, $100 \mathrm{mM}$ $\mathrm{KCl}, \mathrm{pH}=7.0$ ) for $2 \mathrm{~h}$ at $37^{\circ} \mathrm{C}$. The obtained suspension was subjected to seven freeze-thaw cycles and extruded 21 times through a $100 \mathrm{~nm}$ polycarbonate membrane. Finally, the large unilamella vesicles (LUVs) was purified with size exclusion column chromatography (SephadexG-25) and further diluted to $12.9 \mathrm{~mL}$ with HEPES buffer to afford a stock solution with a lipid concentration of $1.0 \mathrm{mM}$ (assuming $100 \%$ of lipids were incorporated into liposomes).

(b) Preparation of LC per-incorporated LUVs: LC $(0.25 \mathrm{mg}$, $100 \mu \mathrm{L}, 2.5 \mathrm{mg} \mathrm{mL}^{-1}$ in $\mathrm{CHCl}_{3}, 10 \mathrm{~mol} \%$ to EYPC) was added to a mixture containing EYPC solution $(2.0 \mathrm{mg}, 80 \mu \mathrm{L}, 25 \mathrm{mg}$ $\mathrm{mL}^{-1}$ in $\left.\mathrm{CHCl}_{3}\right)$ and cholesterol $\left(0.2 \mathrm{mg}, 20 \mu \mathrm{L}, 10 \mathrm{mg} \mathrm{mL}^{-1}\right.$ in $\mathrm{CHCl}_{3}$ ). The solvent was then evaporated by a slow stream of nitrogen, followed by drying under vacuum for $12 \mathrm{~h}$. The obtained lipid membrane was hydrated with $100 \mu \mathrm{L}$ HEPES buffer $(10 \mathrm{mM}$ HEPES, $100 \mathrm{mM} \mathrm{KCl}, \mathrm{pH}=7.0)$ in a shaker for $2 \mathrm{~h}\left(37^{\circ} \mathrm{C}, 180 \mathrm{rad} / \mathrm{min}\right)$. The suspension was subjected to seven freeze-thaw cycles and extruded 21 times through a $100 \mathrm{~nm}$ polycarbonate membrane. Finally, the mixture was purified with size exclusion column chromatography (SephadexG-25) and further diluted to $2.58 \mathrm{~mL}$ with HEPES buffer to afford a stock solution with a lipid concentration of $1.0 \mathrm{mM}$ (assuming $100 \%$ of lipids were incorporated into liposomes).

Four samples were characterized by DLS. In a typical experiment, $2900 \mu \mathrm{L}$ of HEPES buffer (10 mM HEPES, $100 \mathrm{mM}$ $\mathrm{KCl}, \mathrm{pH}=7.0$ ) was transferred to a quartz cuvette followed by the addition of $100 \mu \mathrm{L}$ of above stocked liposome solutions. "LUVs" means the sample prepared by adding (a) stocked liposome solution; "LUVs+LC" means the sample prepared by adding (a) stocked liposome solution and LC (10 $\mu \mathrm{L}$ stock solution in $\mathrm{H}_{2} \mathrm{O}, 10.0 \mu \mathrm{M}$ final concentration); "LC perincorporated LUVs" means the sample prepared by adding (b) stocked liposome solution; and "LC + Triton X-100" means the sample prepared by adding (a) stocked liposome solution and Triton X-100 (10 $\mu \mathrm{L}$ stock solution in $\mathrm{H}_{2} \mathrm{O}, 10.0 \mu \mathrm{M}$ final concentration).

\section{Transmission Electron Microscope Analyse}

Preparation of the TEM sample: LC was dissolved in $\mathrm{H}_{2} \mathrm{O}$ $(10.0 \mu \mathrm{M})$ and incubated in a shaker for $20 \mathrm{~min}\left(37^{\circ} \mathrm{C}, 180\right.$ $\mathrm{rad} / \mathrm{min})$. Then the mixture was dropped in support films and negatively stained by uranyl acetate.

\section{Analyses of Transport Activity of LC}

Preparation of LUVs $\supset$ HPTS: The procedure was similar as for LUVs except a HEPES containing 8-hydroxypyrene1,3,6-trisulfonic acid (HPTS, $1.0 \mathrm{mM}$ ) was used for the hydration process.

LUVs $\supset$ HPTS assay: In a typical experiment, $2900 \mu \mathrm{L}$ of HEPES buffer (10 mM HEPES, $100 \mathrm{mM} \mathrm{KCl,} \mathrm{pH} \mathrm{=} \mathrm{7.0)} \mathrm{was}$ transferred to a quartz cuvette followed by addition of 100 $\mu \mathrm{L}$ above LUVs $\supset$ HPTS solution. The cuvette was placed in the fluorescence instrument with slow stirring condition by a magnetic stirrer equipped in the instrument (at $t=0 \mathrm{~s}$ ). The timedependent change in fluorescence intensity $\left(\lambda_{\mathrm{em}}=510 \mathrm{~nm}\right)$ was monitored at two excitation wavelengths simultaneously $\left(\mathrm{I}_{450}\right.$ $\left.: \lambda_{\mathrm{ex}}=450 \mathrm{~nm}, \mathrm{I}_{405}: \lambda_{\mathrm{ex}}=405 \mathrm{~nm}\right)$, during the addition of base $(30 \mu \mathrm{L}, 0.5 \mathrm{M} \mathrm{KOH}, \Delta \mathrm{pH}=0.8)$ at $t=50 \mathrm{~s}, \mathrm{LC}(10 \mu \mathrm{L}$ stock solution in $\mathrm{H}_{2} \mathrm{O}, 0-50.0 \mu \mathrm{M}$ final concentration) at $t=$ $100 \mathrm{~s}$, and $60 \mu \mathrm{L}$ of $5 \%$ Triton $\mathrm{X}-100$ aqueous solution at $t=$ $550 \mathrm{~s}$. All the temperature was kept at $25^{\circ} \mathrm{C}$ by a stirrer and a temperature controller. Time courses of fluorescence intensity $I_{F}$ were obtained by ratiometric analysis $\left(R=\mathrm{I}_{450} / \mathrm{I}_{405}\right)$ and normalization according to Equation 1,

$$
I_{F}=\left(R-R_{100}\right) /\left(R_{\infty}-R_{100}\right)
$$

where $R_{100}$ is $R$ before addition of transporter and $R_{\infty}$ is $R$ after addition of Triton X-100. The solvent $\mathrm{H}_{2} \mathrm{O}(10 \mu \mathrm{L})$ was also monitored as the fluorescence background. Finally, $I_{t}$ at $550 \mathrm{~s}$ just before the addition of Triton X-100 was defined as transmembrane activity $Y\left(Y=I_{F}-I_{\mathrm{H} 2 \mathrm{O}}\right)$, which was further analyzed with Hill Equation 2 to give effective concentration $\mathrm{EC}_{50}$ and the Hill coefficient $\mathrm{n}$,

$$
Y=Y_{\infty}+\left(Y_{0}-Y_{\infty}\right) /\left(1+\left(\frac{c}{E C_{50}}\right)^{n}\right)
$$

Where $Y_{0}$ is $Y$ in absence of transporter (normally defined as 0 ), $Y_{\infty}$ is $Y$ with excess transporter (normally defined as 1 ) and $c$ is the transporter concentration.

For clarity, the data before the addition of transporter was deleted and time ( $X$-axis) was changed to start from the point of transporter addition (i.e., $t=100 \mathrm{~s}$ was normalized to $t=0 \mathrm{~s}$ ) to the end point of experiment (i.e., $t=550 \mathrm{~s}$ was normalized to $t=450 \mathrm{~s})$.

Ion selectivity: $100 \mu \mathrm{L}$ LUVs $\supset$ HPTS solution was added to $2900 \mu \mathrm{L}$ gently stirred, thermostatic buffer (10 mM HEPES, $100 \mathrm{mM} \mathrm{M}^{+} \mathrm{Cl}^{-}, \mathrm{pH}$ 7.0, where $\mathrm{M}^{+}=\mathrm{Li}^{+}, \mathrm{Na}^{+}, \mathrm{K}^{+}, \mathrm{Rb}^{+}, \mathrm{Cs}^{+}$) in a fluorimetric cell. The time dependent change in fluorescence intensity was monitored and analyzed as described above (final concentration of transporter is $10.0 \mu \mathrm{M}$ ) to obtain the fractional transmembrane activity.

FCCP assay: The vesicles preparation, experimental procedure and data processing were same as above LUVsつHPTS assay except a solution containing carbonyl cyanide-4(trifluoromethoxy)-phenylhydrazone (FCCP, $10 \mu \mathrm{L}$ in HEPES, $5.0 \mu \mathrm{M})$ was added at $t=75 \mathrm{~s}$. Similarly, the initial $100 \mathrm{~s}$ data was removed after normalization. Data analysis and comparison was in the same way as stated above. 


\section{Patch Clamp Measurements}

DPhPC lipid in chloroform was dried under a stream of nitrogen and then under vacuum each for $4 \mathrm{~h}$. The obtained membrane was re-dispersed in decane with a concentration at $20.0 \mathrm{mg} \mathrm{mL}^{-1}$. The solution was used to precoat a $200 \mu \mathrm{m}$ hole of a polystyrene cup held by a chamber upon which a planar lipid bilayer membrane was formed. The cup (cis, ground) and chamber (trans) were filled with $1 \mathrm{~mL} 1.0 \mathrm{M} \mathrm{KCl}$ solution. Formation of membrane was monitored by measuring membrane capacitance. $\mathrm{LC}\left(10 \mu \mathrm{L}\right.$ stock solution in $\mathrm{H}_{2} \mathrm{O}, 5.0 \mu \mathrm{M}$ final concentration) was added to the cis side of the chamber and the solution was stirred for $2 \mathrm{~min}$. Various holding potentials were applied and the channel responses were recorded. $\mathrm{Ag} / \mathrm{AgCl}$ electrodes were used to impose voltages and record currents across the membrane. The patch clamp workstation (Warner Instruments) was used for all experiments. The currents were measured by a Warner BC-535 bilayer clamp amplifier and collected using the Digidata $1550 \mathrm{~A}$ data acquisition system. All data was filtered with 8-pole Bessel filter.

The selectivity calculation of $\mathrm{K}^{+} / \mathrm{Rb}^{+}$: The cup (cis, ground) was filled with $1 \mathrm{~mL} 1.0 \mathrm{M} \mathrm{RbCl}$ solution and the chamber (trans) was filled with $1 \mathrm{~mL} 1.0 \mathrm{M} \mathrm{KCl}$ solution. The other conditions are the same as above. The selectivity of $\mathbf{L C}$ for $\mathrm{K}^{+}$over $\mathrm{Rb}^{+}$, defined as the permeability ratio of two ions, was calculated by using the simplified Goldman-Hodgkin-Katz (GHK) equation (Chui and Fyles, 2012; Chen et al., 2018a):

$$
\frac{P_{K^{+}}}{P_{R b^{+}}}=e^{\frac{-\varepsilon_{r e v} F}{R T}}
$$

where $\varepsilon_{\mathbf{r e v}}$ is the reversal potential (the potential of zero current); $R$ is the universal gas constant $\left(8.314 \mathrm{~J} \mathrm{~K}^{-1} \mathrm{~mol}^{-1}\right) ; T$ the temperature in Kelvin $(300 \mathrm{~K}) ; F$ is the Faraday's constant $\left(96485 \mathrm{C} \mathrm{mol}^{-1}\right) ; P$ is the permeability of $\mathbf{L C}$ for ions.

\section{In vitro Cytotoxicity Assay}

CCK-8 assay was used to evaluate in vitro cytotoxicity of HeLa cells. HeLa cells were first cultured in Dulbecco's modified Eagle medium (DMEM) supplemented with 10\% fetal bovine serum (FBS), penicillin (100 units $\left.\mathrm{mL}^{-1}\right)$, and streptomycin $\left(100 \mathrm{mg} \mathrm{mL}^{-1}\right)$ at $37^{\circ} \mathrm{C}$ in a $5 \% \mathrm{CO}_{2}$ incubator for 3 days. For cytotoxicity assay, HeLa cells were seeded in a 96-well plate at an initial density of 5,000 cells per well in $200 \mu \mathrm{L}$ of complete DMEM medium. After incubating for $24 \mathrm{~h}$, DMEM was replaced with fresh medium, and the cells were treated with samples at varying concentrations. After the coculture for 12,24 , and $36 \mathrm{~h}$, respectively, the medium in each well was removed and replaced by $100 \mu \mathrm{L}$ of fresh DMEM. Then, CCK-8 reagent $(10 \mu \mathrm{L})$ was added to each well and the cells were further incubated for $3 \mathrm{~h}$ at $37^{\circ} \mathrm{C}$. Finally, the absorbance at $450 \mathrm{~nm}$ was recorded by a microplate reader, and the data were averaged from at least six trials.

\section{RESULTS AND DISCUSSION}

Phospholipid derivative LC was synthesized by the following five steps: (1) cyclization of crown ether; (2) reduction of nitro group; (3) coupling of amide; (4) hydrolysis of ester; and (5) condensation of ester (Figure 1). All the compounds were confirmed by both NMR and mass spectra. Although the synthetic procedure is simple, the final product LC cannot be purified by conventional strategies due to its zwitterionic structure. Finally, LC was purified by reverse phase preparative HPLC. The appearance of characteristic shifts of $\mathrm{H}_{a}, \mathrm{H}_{b}$, $\mathrm{H}_{c}$, and $\mathrm{H}_{\mathrm{d}}$ assigned to B18C6 confirmed the successful incorporation of an ion recognition group into a nature lipid Lyso PC (1-palmitoyl-2-hydroxy-sn-glycero-3-phosphocholine) (Figure 2A). LC shows excellent water dispersibility due to its amphiphilic character, and it can self-assembled into vesicles with a diameter of 20-30 nm (Figure 2B), which facilitates all the characterizations under physiological conditions. According to the CPK model, the molecular length of $\mathbf{L C}$ is about $2.3 \mathrm{~nm}$, which is comparable to the length of typical phospholipids (such as EYPC) used in biomimetic membrane. The similar molecular structure and matching molecular length make it possible for LC to associate and insert in the lipid membranes via membrane fusion (Kurihara et al., 2011, 2015).

Then, the influence of LC on the integrity of the biomimetic membrane was detected by DLS method with large unilamellar lipid vesicles (LUVs) as samples. As shown in Figure 2C, the particle size distribution was only slightly larger than that of the blank LUVs after the addition of LC. However, the addition of surfactant Triton X-100 completely decomposed LUVs. It suggests that the addition of LC does not destroy the integrity of the membrane. We also tried to prepare LUVs by preincorporating LC with the EYPC lipids. The comparable vesicle size and narrow particle size distribution further confirmed above suggestion, i.e., LC can associate with LUVs without damaging the lipid membranes. This provides a premise for LC to transport ions across the membrane like natural transporters.

Next, to investigate the transmembrane active of LC, a wellestablished fluorescence assay with LUVs was carried out, in which a $\mathrm{pH}$-sensitive fluorescent probe, 8-hydroxypyrene-1,3,6trisulfonic acid (LUVs $\supset$ HPTS) was entrapped. A pH-gradient $(\Delta \mathrm{pH}=0.8)$ was applied by addition of $\mathrm{KOH}$ solution in the extravesicular buffer, then the addition of transporters induced the $\mathrm{pH}$ gradient collapse via a $\mathrm{H}^{+}$efflux or $\mathrm{OH}^{-}$influx. By monitoring the change in the ratio of fluorescence intensity at $510 \mathrm{~nm}\left(\mathrm{I}_{450} / \mathrm{I}_{405}\right)$ of HPTS (Figure 3A), the ion transport efficiency can be reflected, in which fractional activity was used and compared. As illustrated in Figures 3B,C, a detailed examination of the ion transport of $\mathbf{L C}$ was carried out by varying their concentrations. Compared with Lyso PC, LC exhibited much higher transmembrane activity for $\mathrm{K}^{+}$with an $\mathrm{EC}_{50}$ value of $11.2 \mu \mathrm{M}$ (the concentration of transporter required to achieve 50\% activity). To explore the B18C6 action on the ion transport of LC, cation selectivity were recorded and determined by varying extravesicular cations. As illustrated in Figure 3D, variation of external cations $\left(\mathrm{M}^{+}=\mathrm{Li}^{+}, \mathrm{Na}^{+}, \mathrm{K}^{+}, \mathrm{Rb}^{+}\right.$, and $\mathrm{Cs}^{+}$) provided different transmembrane activity and followed the order $\mathrm{Rb}^{+} \geq \mathrm{Cs}^{+}>\mathrm{K}^{+}>\mathrm{Li}^{+} \geq \mathrm{Na}^{+}$. It is quite different to previous reported B18C6-contained transporters (Chen et al., 2018a; Li et al., 2020), which exhibited $\mathrm{K}^{+}$selectivity due to 

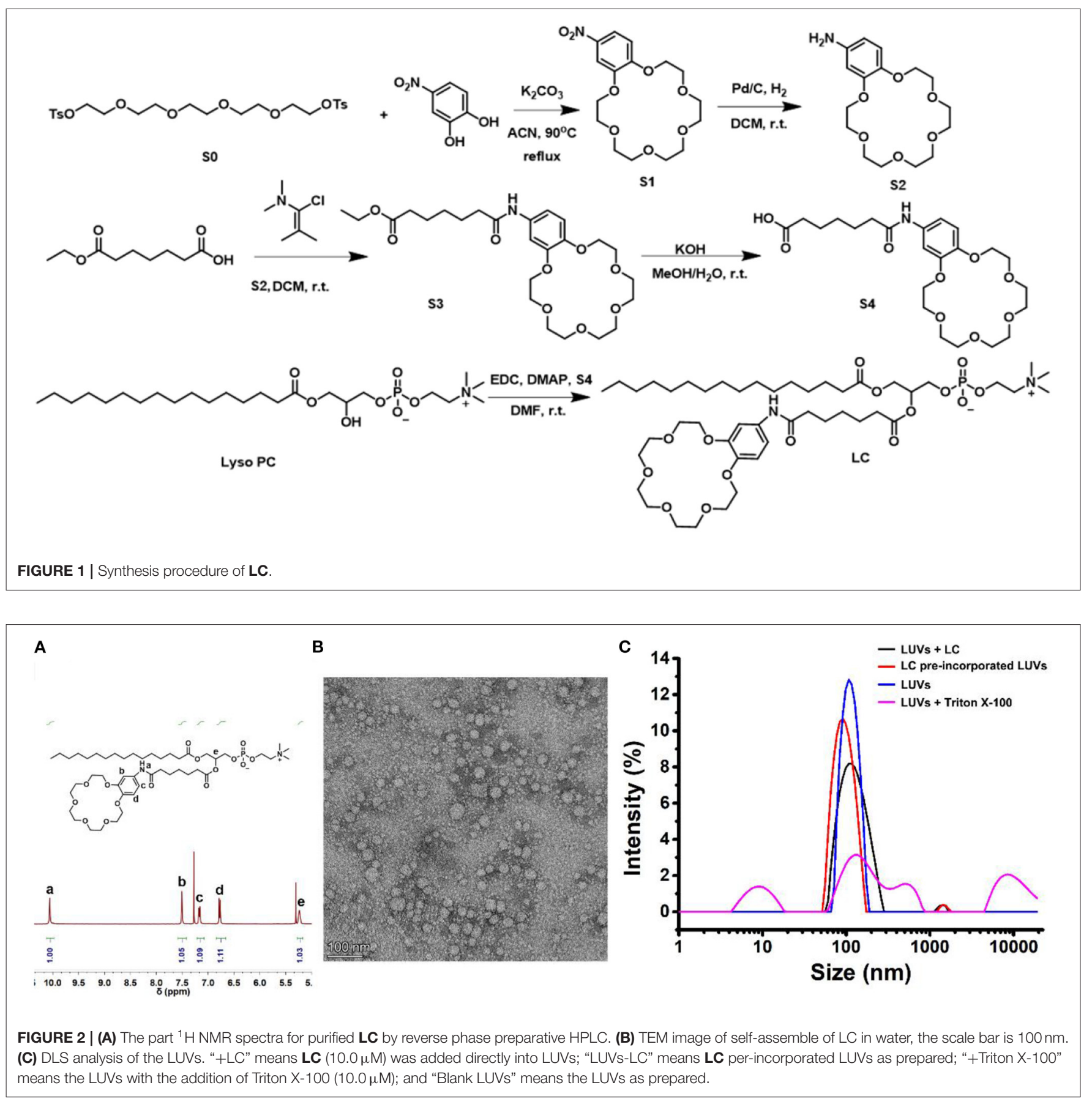

the higher affinity. Compared with $\mathrm{K}^{+}$transport, LC showed a slightly active toward $\mathrm{Li}^{+}$and $\mathrm{Na}^{+}$with smaller sizes, and a highly active toward $\mathrm{Rb}^{+}$and $\mathrm{Cs}^{+}$with bigger sizes. The ionic radii of $\mathrm{Rb}^{+}(1.52 \AA)$ and $\mathrm{Cs}^{+}(1.67 \AA)$ are too large to fit into the cavity of 18 -membered ring crown ethers with a radius of 1.3-1.5 $\AA$ (Kikuchi and Sakamoto, 2000). Therefore, it is considered that a second crown ether molecule participates ion recognition and a sandwich coordination of B18C6 moieties toward $\mathrm{Rb}^{+}$and $\mathrm{Cs}^{+}$may play a key role for ion transport across the lipid bilayers (Kim et al., 1999; Lamoureux and Roux,
2006; Sun et al., 2015; Schneider et al., 2017). Based on the mechanism suggested by Smith et al. (McNally et al., 2008), that is, the relay mechanism by a dimeric or a tetrameric aggregates (Figure 3E), the ion selectivity shown by LC indicates that its transport mechanism is more inclined to the latter. In order to determine whether the ion transport is via a $\mathrm{H}^{+} / \mathrm{M}^{+}$antiport or a $\mathrm{M}^{+} / \mathrm{OH}^{-}$symport mechanism, the transmembrane activity of LC in the presence of carbonyl cyanide-4-(trifluoromethoxy)phenylhydrazone (FCCP, a $\mathrm{H}^{+}$selective transporter) were studied by LUVsつHPTS assay. As illustrated in Figure 3F, the 
A

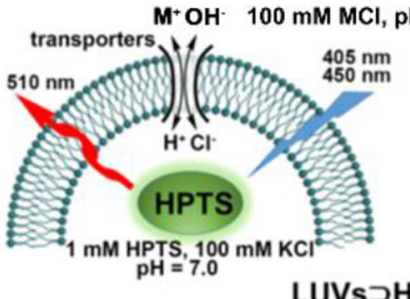

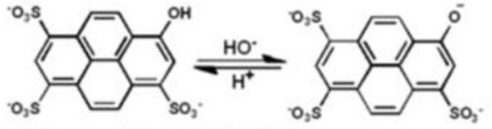

$\mathrm{pH}$ sensitive HPTS fluorescent dye

\section{LUVsدHPTS assay}
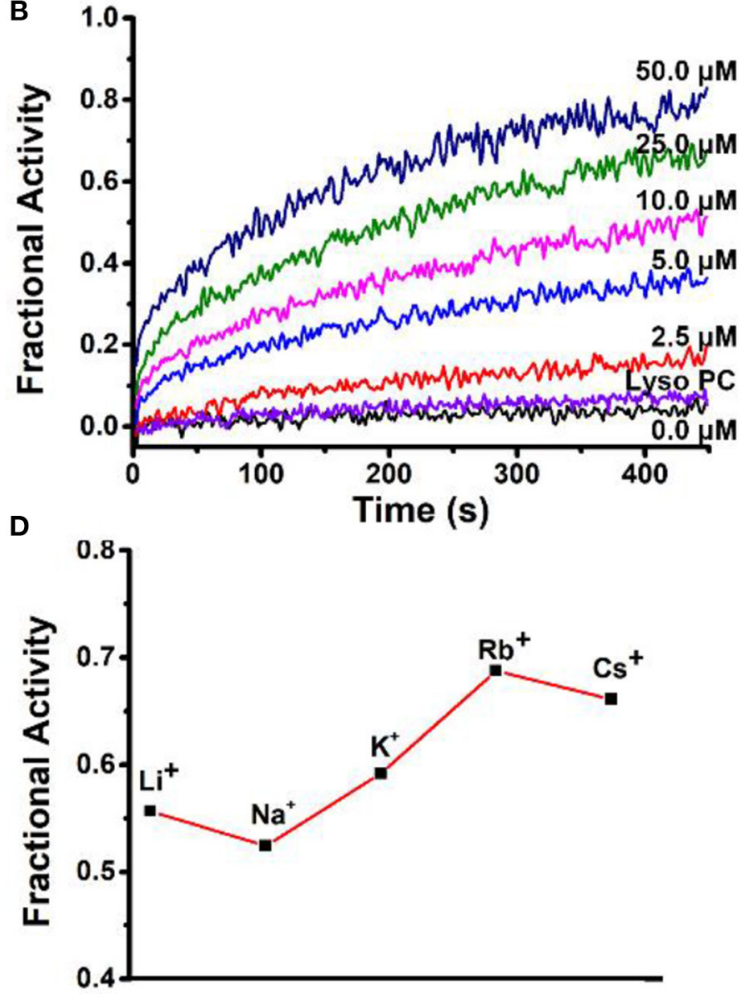

C

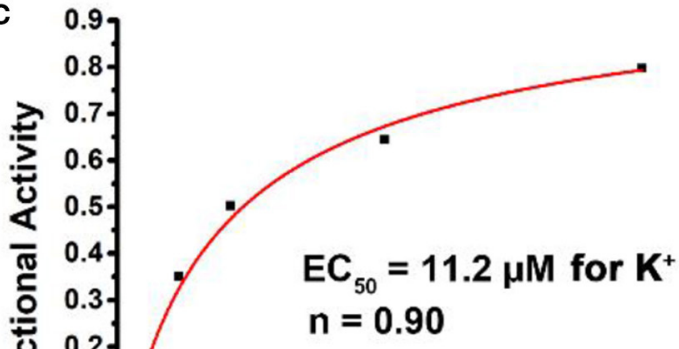

$\mathrm{n}=\mathbf{0 . 9 0}$

$\mathbf{F}$

10 Concentration $(\mu \mathrm{M})$
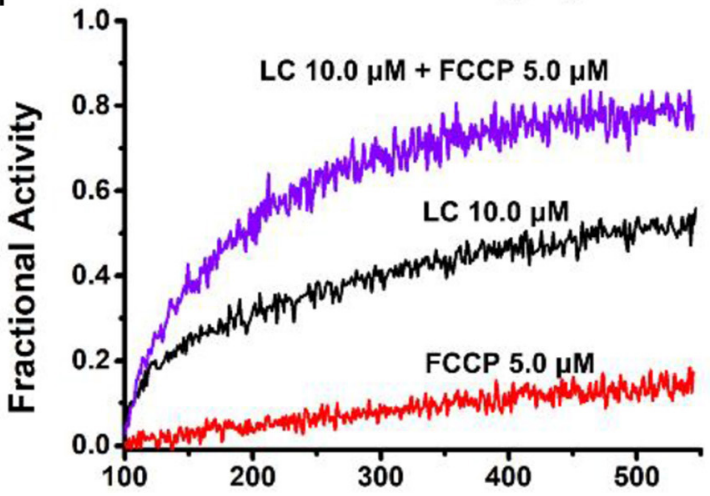

E The proposed relay mechanism for ion transport:

Time (s)

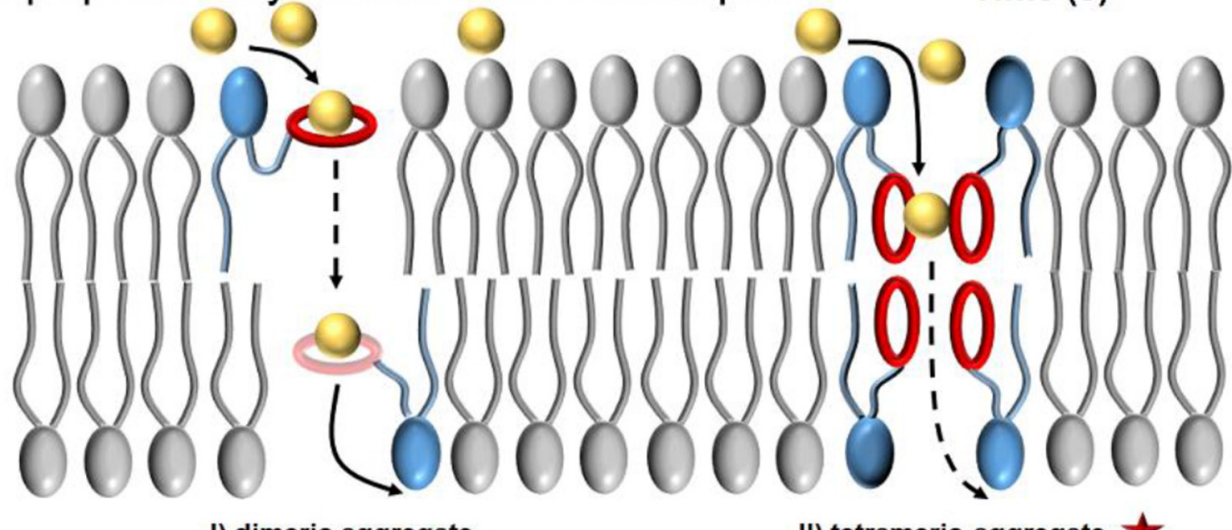

I) dimeric aggregate

II) tetrameric aggregate

FIGURE 3 | (A) Schematic illustration of the pH-sensitive LUVs $\supset$ HPTS assay. (B) Ion transport activities of LC in different concentrations $(0.0 \sim 50.0 \mu \mathrm{M}$, final concentrations). The activity of Lyso PC at $50.0 \mu \mathrm{M}$ is compared. (C) Concentration-activity curves for $\mathrm{K}^{+}$transport. The red lines are the fitted curves from Hill equation (Equation 2) and $E_{50}$ is $11.2 \mu \mathrm{M}$ for $\mathrm{K}^{+}$. (D) Ion selectivity LUVs $\supset H P T S$ assay of $\mathbf{L C}$ at $10.0 \mu \mathrm{M}$. (E) Schematic representation of the proposed mechanism for ion transport of $\mathbf{L C}$ across a lipid membrane. (F) FCCP assay, the comparison of ion transport activity of $\mathbf{L C}(10.0 \mu \mathrm{M})$ in the absence and presence of FCCP at $5.0 \mu \mathrm{M}$, respectively. The activity of FCCP was observed and compared. 

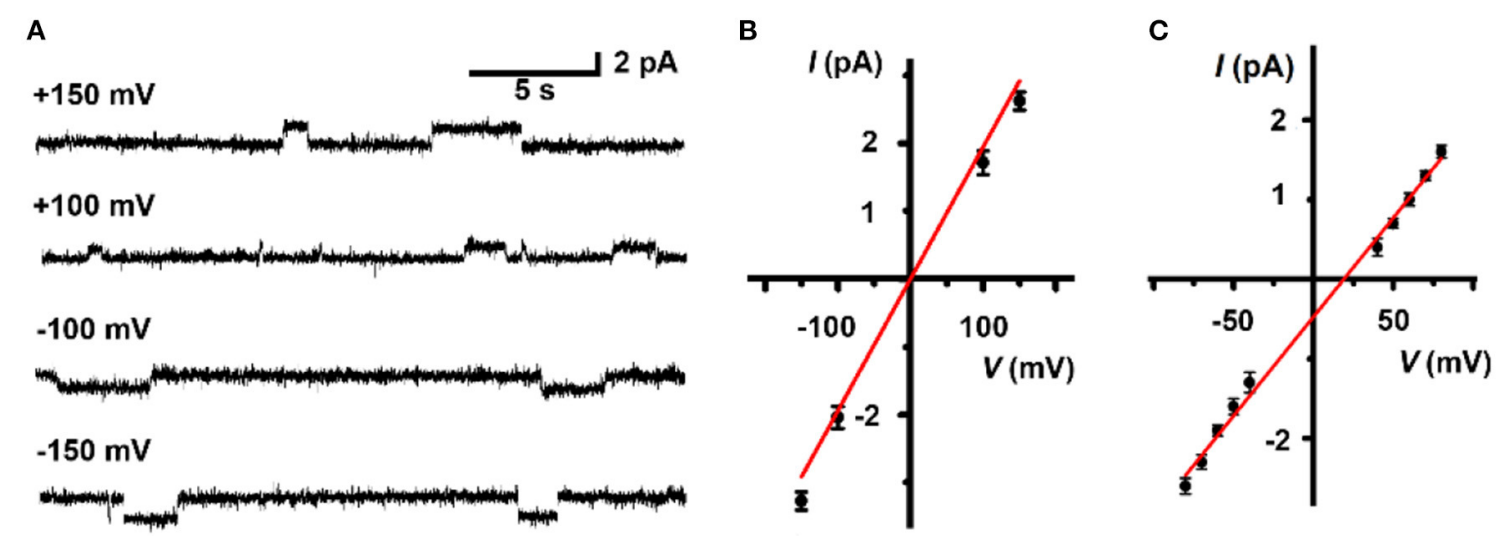

FIGURE 4 | (A) Representative current recording and (B) linear I-V plots of LC $(5.0 \mu \mathrm{M})$ at various holding potentials in a symmetrical $1 \mathrm{M}$ KCl solution. (C) Linear I-V plots of $\mathbf{L C}(5.0 \mu \mathrm{M})$ in an asymmetrical solution. $1.0 \mathrm{M} \mathrm{KCl}$ in trans chamber and $1.0 \mathrm{M} \mathrm{RbCl}$ in cis chamber. The reversal potential (the potential of zero current) is $18.9 \mathrm{mV}$.

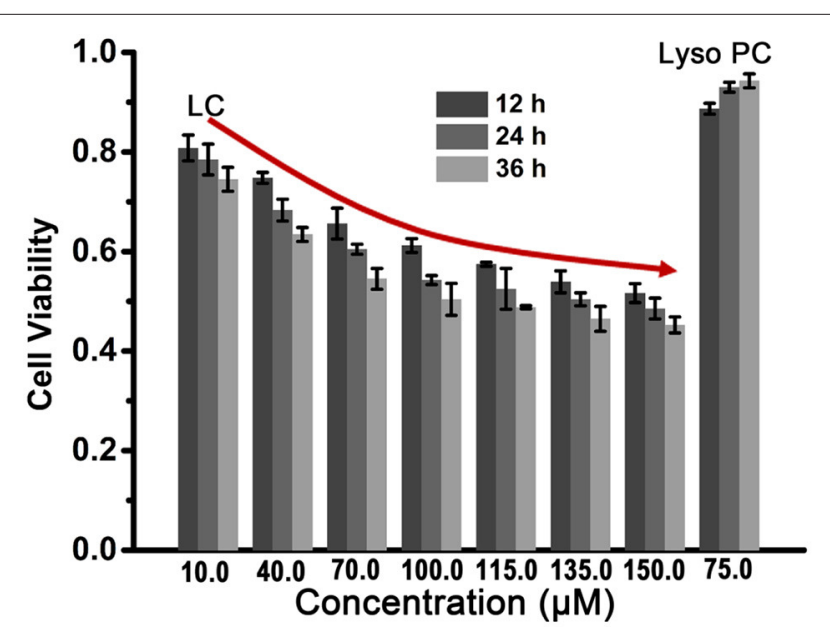

FIGURE 5 | The cytotoxicity analysis of $\mathbf{L C}$ to HeLa cells determined by CCK-8 assay. Lyso PC at $75.0 \mu \mathrm{M}$ was used as a contrast.

addition of FCCP caused obviously increased activity (from 50 to $80 \%$ by adding $5.0 \mu \mathrm{M}$ FCCP), in contrast, the same amount of FCCP itself resulted $<10 \%$ activity. This result support that $\mathrm{M}^{+} / \mathrm{OH}^{-}$symport mechanism balanced the charges inside and outside of the LUVs (Saha et al., 2016; Chen et al., 2018b, 2021).

Finally, to further scrutinize the transport mechanism of LC, a patch-clamp technique on planar lipid bilayer membranes (BLMs) was employed to record single-channel current traces. The addition of LC led to conductance traces at various holding potentials and the representative signals are shown in Figure 4A. The appearance of regular square-like signals with considerably long opening times suggests that LC transports ions as a stable channel or pore across the bilayer membrane. The signals scales linearly in current-voltage relationships in the range of -150 to $+150 \mathrm{mV}$ (Figure 4B), and the ohmic I-V profiles allows the evaluation of a single channel conductivity of 17
pS, suggesting effective ion transport across the BLMs. We further performed a patch-clamp assay to quantitatively compare the permeability ratios of these ions by determining reversal potentials (Figure $4 \mathrm{C}$ ), which revealed a $\mathrm{K}^{+} / \mathrm{Rb}^{+}$permeability ratio $\left(\mathrm{P}_{\mathrm{K}}^{+} / \mathrm{P}_{\mathrm{Rb}}^{+}\right)$of 0.48 by the calculation of Goldman-HodgkinKatz $(\mathrm{GHK})$ equation. Combined with the results of ion selectivity in LUVs $\supset$ HPTS assay, the channel-like current signal further inspired us to speculate that LC transports ion through a channel mechanism of a tetrameric aggregate as proposed in Scheme 1.

Based on the amphipathic characteristic and the efficient ability for ion transport of LC, we expect that LC can exhibit potent anticancer ability by changing membrane permeability and disrupting ion homeostasis (Gokel and Negin, 2013). In order to verify above expectation, a series of LC cytotoxicity experiments were carried out and HeLa cells were selected as the cell model. After fed HeLa cells with different concentrations of LC for 12, 24, and $36 \mathrm{~h}$, respectively, the cell viability was determined by CCK- 8 assay and expressed by the ratio to the control group without any samples. As illustrated in Figure 5, LC displays considerable toxicity toward HeLa cells, and the cell viability exhibits a dose-response, that is, the cytotoxicity increased with the increase of concentration $\left(\mathrm{IC}_{50}\right.$ $\approx 100.0 \mu \mathrm{M}$ for $36 \mathrm{~h}$ co-culture). However, Lyso PC shows good cytocompatibility even when the concentration increases to $75.0 \mu \mathrm{M}$ (maximum soluble concentration), and the cell viability is higher than $88 \%$. These preliminary results show that LC has a potential application as an anticancer drug, although its cytotoxicity is lower than that of classical anticancer drugs, such as doxorubicin hydrochloride with $\mathrm{IC}_{50}$ value of $4.3 \mu \mathrm{M}$ under the same conditions (Zhou et al., 2020).

\section{CONCLUSION}

In conclusion, we designed and synthesized a water-soluble phospholipid LC with an ion recognition group B18C6 for cation transport across the lipid membranes. Both vesicle 
and planar lipid bilayer experiments verify the efficient ion transport; the change of cation species and the addition of cotransporter FCCP confirm the $\mathrm{M}^{+} / \mathrm{OH}^{-}$symport mechanism. The selectivity of $\mathrm{Rb}^{+}$over $\mathrm{K}^{+}\left(\mathrm{P}_{\mathrm{K}}^{+} / \mathrm{P}_{\mathrm{Rb}}^{+}=\right.$ 0.48 ) indicates a sandwich interaction between the ions and B18C6. Combined with the channel current signal of LC, a tetrameric aggregate is proposed as the main active structure of ion transport via a relay mechanism. In addition, the anticancer activity of LC on HeLa cells provides a possibility for its application in cancer chemotherapy. Through reasonable molecular design, we hope to provide new opportunities for the development of more effective ion transporters with well-defined structures.

\section{DATA AVAILABILITY STATEMENT}

The original contributions presented in the study are included in the article/supplementary material, further inquiries can be directed to the corresponding author.

\section{REFERENCES}

Appleman, J. R., and Lienhard, G. E. (1989). Kinetics of the purified glucose transporter. Direct measurement of the rates of interconversion of transporter conformers. Biochemistry 28, 8221-8227. doi: 10.1021/bi00446a038

Bröer, S. (2008). Amino acid transport across mammalian intestinal and renal epithelia. Physiol. Rev. 88, 249-286. doi: 10.1152/physrev.00018.2006

Chen, F., Shen, J., Li, N., Roy, A., Ye, R., Ren, C., et al. (2020). Pyridine/oxadiazolebased helical foldamer ion channels with exceptionally high $\mathrm{K}+/ \mathrm{Na}+$ selectivity. Angew. Chem. Int. Ed. 59, 1440-1444. doi: 10.1002/anie.201906341

Chen, H., Liu, Y., Cheng, X., Fang, S., Sun, Y., Yang, Z., et al. (2021). Self-assembly of size-controlled m-Pyridine-urea oligomers and their biomimetic chloride ion channels. Angew. Chem. Int. Ed. doi: 10.1002/anie.202102174 [Epub ahead of print].

Chen, S., Wang, Y., Nie, T., Bao, C., Wang, C., Xu, T., et al. (2018a). An artificial molecular shuttle operates in lipid bilayers for ion transport. J. Am. Chem. Soc. 140, 17992-17998. doi: 10.1021/jacs.8b09580

Chen, S., Zhao, Y., Bao, C., Zhou, Y., Wang, C., Lin, Q., et al. (2018b). A welldefined unimolecular channel facilitates chloride transport. Chem. Commun. 54, 1249-1252. doi: 10.1039/C7CC09200H

Chui, J. K. W., and Fyles, T. M. (2012). Ionic conductance of synthetic channels: analysis, lessons, and recommendations. Chem. Soc. Rev. 41, 148-175. doi: 10.1039/C1CS15099E

Elliott, E. K., Stine, K. J., and Gokel, G. W. (2008). Air-water interfacial behavior of amphiphilic peptide analogs of synthetic chloride ion transporters. J. Membr. Sci. 321, 43-50. doi: 10.1016/j.memsci.2008.01.048

Fyles, T. M. (2007). Synthetic ion channels in bilayer membranes. Chem. Soc. Rev. 36, 335-347. doi: 10.1039/B603256G

Gokel, G. W., and Negin, S. (2013). Synthetic ion channels: from pores to biological applications. Acc. Chem. Res. 46, 2824-2833. doi: 10.1021/ar400026x

Kikuchi, Y., and Sakamoto, Y. (2000). Complex formation of alkali metal ions with 18-crown-6 and its derivatives in 1,2-dichloroethane. Anal. Chim. Acta 403, 325-332. doi: 10.1016/S0003-2670(99)00648-0

Kim, D. S., and Sessler, J. L. (2015). Calix [4] pyrroles: versatile molecular containers with ion transport, recognition, and molecular switching functions. Chem. Soc. Rev. 44, 532-546. doi: 10.1039/C4CS00157E

Kim, J., Shamsipur, M., Huang, S., Huang, R., and Dye, J. (1999). Sandwich and mixed sandwich complexes of the cesium ion with crown ethers in nitromethane. J. Am. Chem. Soc. 103, 5615-5620. doi: 10.1021/jp990685t

Kurihara, K., Okura, Y., Matsuo, M., Toyota, T., Suzuki, K., and Sugawara, T. (2015). A recursive vesicle-based model protocell with a primitive model cell cycle. Nat. Commun. 6, 1-7. doi: 10.1038/ncomms9352

\section{AUTHOR CONTRIBUTIONS}

$\mathrm{CB}$ proposed and supervised the project. CW and HY carried out the synthesis, characterizations, and data collection. YX and SP performed the experiments of cytotoxicity assay. CB and LZ oversaw the paper with edits from all authors. All the authors discussed the results and commented on the manuscript.

\section{FUNDING}

This work was supported by the National Key Research and Development Project (2019YFA0110500) and NSFC (Grant Nos. 21472044).

\section{ACKNOWLEDGMENTS}

The authors thank Research Centre of Analysis and Test of East China University of Science and Technology for the help on the characterizations.

Kurihara, K., Tamura, M., Shohda, K., Toyota, T., Suzuki, K., and Sugawara, T. (2011). Self-reproduction of supramolecular giant vesicles combined with the amplification of encapsulated DNA. Nat. Chem. 3, 775-781. doi: $10.1038 /$ nchem. 1127

Lamoureux, G., and Roux, B. (2006). Absolute hydration free energy scale for alkali and halide ions established from simulations with a polarizable force field. $J$. Phys. Chem. B 110, 3308-3322. doi: 10.1021/jp056043p

Lang, F., Föller, M., Lang, K. S., Lang, P. A., Ritter, M., Gulbins, E., et al. (2005). Ion channels in cell proliferation and apoptotic cell death. J. Membrane Biol. 205, 147-157. doi: 10.1007/s00232-005-0780-5

Li, N., Chen, F., Shen, J., Zhang, H., Wang, T., Ye, R., et al. (2020). Buckyball-based spherical display of crown ethers for de novo custom design of ion transport selectivity. J. Am. Chem. Soc. 142, 21082-21090. doi: 10.1021/jacs.0c09655

McNally, B. A., O'neil, E. J., Nguyen, A., and Smith, B. D. (2008). Membrane transporters for anions that use a relay mechanism. J. Am. Chem. Soc. 130, 17274-17275. doi: 10.1021/ja8082363

Mosgaard, L. D., and Heimburg, T. (2013). Lipid ion channels and the role of proteins. Acc. Chem. Res. 46, 2966-2976. doi: 10.1021/ar4000604

Saha, T., Gautam, A., Mukherjee, A., Lahiri, M., and Talukdar, P. (2016). Chloride transport through supramolecular barrel-rosette ion channels: lipophilic control and apoptosis-inducing activity. J. Am. Chem. Soc. 138, 16443-16451. doi: 10.1021/jacs.6b10379

Schneider, S., Licsandru, E.-D., Kocsis, I., Gilles, A., Dumitru, F., Moulin, E., et al. (2017). Columnar self-assemblies of triarylamines as scaffolds for artificial biomimetic channels for ion and for water transport. J. Am. Chem. Soc. 139, 3721-3727. doi: 10.1021/jacs.6b12094

Shank, L. P., Broughman, J. R., Takeguchi, W., Cook, G., Robbins, A. S., Hahn, L., et al. (2006). Redesigning channel-forming peptides: amino acid substitutions that enhance rates of supramolecular self-assembly and raise ion transport activity. Biophys. J. 90, 2138-2150. doi: 10.1529/biophysj.105.070078

Si, W., Xin, P., Li, Z. T., and Hou, J. L. (2015). Tubular unimolecular transmembrane channels: construction strategy and transport activities. Acc. Chem. Res. 48, 1612-1619. doi: 10.1021/acs.accounts.5b00143

Sun, Z., Barboiu, M., Legrand, Y.-M., Petit, E., and Rotaru, A. (2015). Highly selective artificial cholesteryl crown ether $\mathrm{K}^{+}$channels. Angew. Chem. Int. Ed. 54, 14473-14477. doi: 10.1002/anie.201506430

Wu, X., Howe, E. N., and Gale, P. A. (2018). Supramolecular transmembrane anion transport: new assays and insights. Acc. Chem. Res. 51, 1870-1879. doi: 10.1021/acs.accounts.8b00264

Zaydman, M. A., Silva, J. R., and Cui, J. (2012). Ion channel associated diseases: overview of molecular mechanisms. Chem. Rev. 112, 6319-6333. doi: $10.1021 / \mathrm{cr} 300360 \mathrm{k}$ 
Zhang, C., Deng, X., Wang, C., Bao, C., Yang, B., Zhang, H., et al. (2019). Helical supramolecular polymer nanotubes with wide lumen for glucose transport: towards the development of functional membrane-spanning channels. Chem. Sci. 10, 8648-8653. doi: 10.1039/C9SC02336D

Zheng, S. P., Huang, L. B., Sun, Z., and Barboiu, M. (2020). Self-assembled artificial ion-channels toward natural selection of functions. Angew. Chem. Int. Ed. 60, 566-597. doi: 10.1002/anie.201915287

Zhou, Y., Chen, R., Yang, H., Bao, C., Fan, J., Wang, C., et al. (2020). Light-responsive polymersomes with a charge-switch for targeted drug delivery. J. Mater. Chem. B. 8, 727-735. doi: 10.1039/C9TB0 $2411 \mathrm{E}$
Conflict of Interest: The authors declare that the research was conducted in the absence of any commercial or financial relationships that could be construed as a potential conflict of interest.

Copyright (c) 2021 Wang, Yang, Xiang, Pang, Bao and Zhu. This is an open-access article distributed under the terms of the Creative Commons Attribution License (CC BY). The use, distribution or reproduction in other forums is permitted, provided the original author(s) and the copyright owner(s) are credited and that the original publication in this journal is cited, in accordance with accepted academic practice. No use, distribution or reproduction is permitted which does not comply with these terms. 